\title{
PENGARUH PENGGUNAAN MACROMEDIA SEBAGAI MEDIA PEMBELAJARAN PADA STANDAR KOMPETENSI INSTALASI VIDEO GAME DI SMK GAMALIEL 1 MADIUN
}

\author{
Hendrik Pratama ${ }^{1}$, Nunus Wijoseno ${ }^{2}$ \\ ${ }^{1}$ Prodi Pendidikan Teknik Elektro, FPTK, IKIP PGRI Madiun \\ Madiun, 63118, Indonesia \\ ${ }^{2}$ Prodi Pendidikan Teknik Elektro, FPTK, IKIP PGRI Madiun \\ Madiun, 63118, Indonesia \\ Email : pratama2326@ikippgrimadiun.ac.id; wijosenonunus@gmail.com
}

\begin{abstract}
ABSTRAK
Media pembelajaran visual yang secara umum di jumpai pada beberapa Sekolah Menengah Kejuruan (SMK) adalah media pembelajaran yang hanya terdiri dari gambargambar, tulisan-tulisan, dan juga grafik-grafik. Media pembelajaran ini banyak dijumpai berupa gambar-gambar di dinding, gambar- gambar di buku-buku LKS, dan lain sebagainya.Media visual seperti di sebutkan diatas belum mampu meningkatkan prestasi belajar siswa, dimana justru dengan gambar-gambar itu siswa malah kebingungan didalam mencerna suatu materi pelajaran. Dan pada akhirnya pada saat dilakukan evaluasi berupa ulangan para siswa tidak mampu menjawab pertanyaan dengan baik. Kelemahan utama dari media pembelajaran visual diatas adalah belum mampu menggerakkan kemampuan psikomotorik dan kreatifitas siswa.Media pembelajaran Macromedia merupakan salah satu pilihan terbaik untuk menggantikan beberapa media pembelajaran visual diatas, karena dengan media pembelajaran Macromedia ini, siswa dapat melihat sebuah gambar, tulisan, ataupun grafik dalam bentuk animasi gerak. Dengan animasi gerak inilah, kemampuan psikomotorik dan kreatifitas siswa akan dilatih, dan pada akhirnya akan mempengaruhi prestasi belajar siswa .
\end{abstract}

Kata Kunci : Macromedia, Instalasi Instalasi Video Game, Prestasi Belajar Siswa.

\section{Pendahuluan}

Sarana dan prasarana penunjang pelaksanaan pembelajaran di Sekolah Menengah Kejuruan (SMK) mutlak di perlukan sebagai bentuk jaminan terhadap lulusan SMK yang di harapkan mampu bersaing di tengah-tengah masyarakat. Meskipun demikian belum ada sekolah manapun yang mampu mencukupi seluruh kebutuhan sarana dan prasarana tersebut.

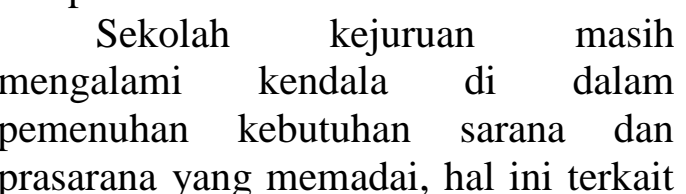

dengan terbatasnya pendanaan yang di miliki sekolah. Pemerintah tidak hentihentinya memberikan bantuan pengadaan sarana dan prasarana, akan tetapi sampai kini belum dapat di kategorikan terpenuhi 100\%. Masih banyak kekurangan dimana-mana sehingga pengaruhnya terhadap prestasi belajar siswa menjadi kurang optimal.

Media pembelajaran merupakan salah satu bentuk sarana prasarana itu, dimana banyak di jumpai berbagai bentuk dan jenis dari media pembelajaran. Namun perlu di sadari bahwa media pembelajaran hanya 
merupakan alat bantu yang belum tentu dapat menjamin 100\% kebutuhan yang ada.

Banyak jenis-jenis media pembelajaran visual yang di pakai oleh guru di dalam memberikan materi di depan kelas, hal ini dalam rangka membantu guru di dalam upaya menyampaikan materi di depan kelas.

Media pembelajaran visual adalah media pembelajaran yang mampu memberikan gambaran materi dimana hal ini hanya terwakili oleh beberapa gambar, tulisan, dan grafik saja. Media pembelajaran ini dapat dijumpai berupa gambar- gambar di buku, gambargambar di dinding, tulisan-tulisan, serta grafik-grafik yang merupakan perwujudan sebuah materi pelajaran yang ada. Pada umumnya dengan melihat gambar ini, seorang siswa diharapkan sudah bisa mampu menyerap materi pelajaran.

Media pembelajaran visual yang hanya berupa gambar, tulisan dan grafik sebagaimana dijelaskan diatas, belum mampu memberikan kontribusi terhadap prestasi belajar siswa, justru terkadang siswa tidak mampu mengerti maksud dari gambar yang dilihatnya, kadang juga siswa justru kebingungan di dalam menelaah beberapa grafik yang mereka lihat.

Dari pengamatan peneliti, bahwa prestasi belajar siswa yang menerima pembelajaran hanya dengan media pembelajaran visual seperti gambar, tulisan dan grafik, tidak menunjukkan hasil yang maksimal, bahkan dari beberapa indikator penilaian yang ada, prestasi belajar mereka sungguh mengecewakan. Hal ini dapat diamati dari hasil nilai harian, ulangan harian, maupun ulangan semester yang telah dilaksanakan.

Pada proses pembelajaran di Sekolah Menengah Kejuruan ( SMK ) khususnya di SMK Gamaliel 1 Madiun kelas XII AV.B, prestasi belajar pada standar kompetensi "Instalasi Video Game" menunjukkan beberapa indikator yg kurang memuaskan diantaranya dapat disebutkan berikut ini:

1. Nilai rata-rata ulangan harian yang mampu dicapai kelas XII AV.B adalah 7,12 (tujuh koma satu dua) dengan predikat tidak tuntas.

2. Nilai rata-rata penugasan yang mampu di capai kelas XII AV.B pada standar kompetensi "Instalasi Video Game" hanya mencapai 7,27 (tujuh koma dua tujuh) dengan predikat tidak tuntas.

3. Nilai rata-rata keaktifan yang di capai kelas XII AV.B pada standar kompetensi "Instalasi Video Game" hanya mencapai 6,88 (enam koma delapan delapan) dengan predikat tidak aktif.

Perlu adanya upaya perbaikan didalam penggunaan media pembelajaran visual yang ada, dengan harapan bahwa prestasi belajar siswa kelas XII AV.B ini nantinya mengalami peningkatan sesuai dengan yang dharapkan. Perbaikan ini meliputi perbaikan bentuk dan penyempurnaan pola visual yang ada. Sehingga nantinya didalam memahami suatu gambar, tulisan ataupun grafik, siswa akan dengan mudah menerima materi yang diberikan.

Hal-hal diatas mendasari peneliti untuk menemukan satu bentuk media pembelajaran visual baru yang mungkin lebih dapat diterima oleh peserta didik, media visual baru tersebut sementara ini belum banyak dipergunakan di Sekolah sekolah kejuruan, sehingga perlu untuk dikaji lebih mendalam dan komprehensif.

Media pembelajaran visual yang baru ini dituangkan dalam bentuk laporan penelitian dengan judul "Penggunaan Macromedia Sebagai 
Media Pembelajaran pada Siswa Kelas XII AV.B Semester Genap Standar Kompetensi Instalasi Video Game di SMK Gamaliel 1 Madiun".

Dengan penggunaan media pembelajaran Macromedia ini, para siswa tidak hanya melihat obyek-obyek gambar, tulisan dan grafik yang diam, melainkan obyek-obyek gambar bergerak dalam bentuk animasi. Dengan animasi inilah, daya psikomotorik dan kreatifitas siswa akan meningkat, dan pada akhirnya akan berpengaruh pada prestasi belajar di kelas.

\section{Metode}

Prosedur penelitian yang di lakukan oleh peneliti adalah meliputi :

1. Inventarisasi nilai awal, yakni pengumpulan nilai awal yang telah di capai siswa meliputi nilai ulangan harian, nilai semesteran, nilai sikap dari kelas XII AV.B. Nilai ini di dapatkan dari guru bidang studi yang memberikan pelajaran sebelumnya. Inventarisasi ini di jadikan bahan observasi awal dan merupakan bahan siklus I

2. Tindakan, yakni pada standar kompetensi yang sama di lakukan proses pembelajaran dengan menggunakan macromedia sebagai media pembelajarannya. Hal ini merupakan tindakan perbaikan hasil prestasi belajar siswa yang telah di capai pada pembelajaran sebelumnya.

3. Setelah di lakukan tindakan, kemudian melakukan kegiatan observasi berupa perubahan sikap siswa terhadap proses pembelajarannya, dan pengadaan kegiatan ulangan harian, observasi ini kemudian di jadikan bahan untuk siklus II.

4. Tindakan lanjutan, yakni penggunaan macromedia pada standar kompetensi yang sama, tetapi dengan penerapan pola diskusi kelompok, hal ini dalam upaya peningkatan proses pembelajaran dari macromedia itu sendiri.

5. Observasi akhir, yakni proses pengumpulan nilai kemajuan prestasi belajar siswa, dan selanjutnya hasil observasi ini di jadikan indikator kemajuan prestasi belajar siswa pada siklus ke III

6. Data observasi pada siklus I, II dan siklus III kemudian di analisis dan di evaluasi secara kualitatif, kemudian di lakukan refleksi keberhasilan proses pembelajaran standar kompetensi "Instalasi Video Game".

7. Menyimpulkan, setelah dilakukan refleksi pada masing- masing siklus maka tindakan selanjutnya adalah membuat kesimpulan akhir.

\section{Hasil Penelitian}

Dari observasi yang di lakukan mulai dari siklus II dan siklus III maka dapat di lihat bahwa macromedia mampu meningkatkan prestasi belajar siswa kelas XII AV.B SMK Gamaliel 1 Madiun khususnya pada standar kompetensi "Instalasi Video Game". Perkembangan kemajuan terjadi pada siklus II maupun III, ada kecenderungan terjadi peningkatan pada semua indikator penilaian.

Menyikapi hal ini maka dapat di jabarkan beberapa penjelasan sebagai berikut:

a. Macromedia merupakan teknologi tepat guna di dalam membantu menyampaikan informasi di sekolah, informasi di maksud adalah materi pembelajaran. Dengan macromedia mampu meningkatkan daya kreatifitas, motivasi belajar, dan pada akhirnya mampu meningkatkan prestasi belajar siswa secara keseluruhan.

b. Macromedia mampu memberikan gambaran secara utuh terhadap 
materi pembelajaran yang di berikan sekolah, sehingga mampu meningkatkan tingkat penyerapan materi pada semua siswa kelas XII AV.B SMK Gamaliel 1 Madiun.

c. Peningkatan prestasi dari aspek nilai harian, nilai penugasan dan nilai sikap tampak pada siklus II (kedua). Peningkatan ini bila dibandingkan dengan data nilai yang di dapatkan dari guru bidang studi. Hal ini terkait dengan penerapan pembelajaran yang menggunakan macromedia.

d. Peningkatan prestasi dari aspek nilai ulangan harian dan nilai penugasan meningkat dengan pesat pada siklus III (ketiga), hal ini di karenakan penggunaan macromedia di dukung dengan kegiatan diskusi kelompok setelah proses pembelajaran berupa penyampaian materi selesai di berikan oleh peneliti.

e. Detail perkembangan prestasi dapat di perlihatkan pada tabel berikut ini:

Tabel 1.1. Rekapitulasi

Perkembangan Siklus I, Siklus II dan Siklus III

\begin{tabular}{|c|c|c|c|c|c|}
\hline \multirow{2}{*}{$\begin{array}{l}\mathrm{N} \\
\mathrm{O}\end{array}$} & \multirow[b]{2}{*}{ Aspek } & \multicolumn{3}{|c|}{$\begin{array}{l}\text { Siklus } \\
\text { Pembelajaran }\end{array}$} & \multirow[b]{2}{*}{ Ket } \\
\hline & & I & II & III & \\
\hline \multirow{4}{*}{1} & $\begin{array}{l}\text { Nilai } \\
\text { Harian }\end{array}$ & & & & \\
\hline & $\begin{array}{l}\text { a. Siswa } \\
\text { yang tuntas }\end{array}$ & 13 & 26 & 38 & meningkat \\
\hline & $\begin{array}{l}\text { b. } \\
\text { Prosentase } \\
\text { ketuntasan }\end{array}$ & $\begin{array}{l}28 \\
\%\end{array}$ & $57 \%$ & $84 \%$ & meningkat \\
\hline & $\begin{array}{l}\text { c. Nilai } \\
\text { rata-rata/ } \\
\text { kelas }\end{array}$ & $\begin{array}{l}7, \\
12\end{array}$ & 7,52 & 7,73 & meningkat \\
\hline \multirow{4}{*}{2} & $\begin{array}{l}\text { Nilai } \\
\text { Penugasan }\end{array}$ & & & & meningkat \\
\hline & $\begin{array}{l}\text { a. Siswa } \\
\text { yang tuntas }\end{array}$ & 16 & 28 & 41 & meningkat \\
\hline & $\begin{array}{l}\text { b. } \\
\text { Prosentase } \\
\text { ketuntasan }\end{array}$ & $\begin{array}{l}35 \\
\%\end{array}$ & $62 \%$ & $91 \%$ & meningkat \\
\hline & $\begin{array}{l}\text { c. Nilai } \\
\text { rata-rata/ } \\
\text { kelas } \\
\end{array}$ & $\begin{array}{l}7, \\
27 \\
\end{array}$ & 7,6 & 7,81 & meningkat \\
\hline \multirow[t]{2}{*}{3} & Nilai Sikap & & & & meningkat \\
\hline & $\begin{array}{l}\text { a. Siswa } \\
\text { yang aktif }\end{array}$ & 21 & 35 & 41 & meningkat \\
\hline
\end{tabular}

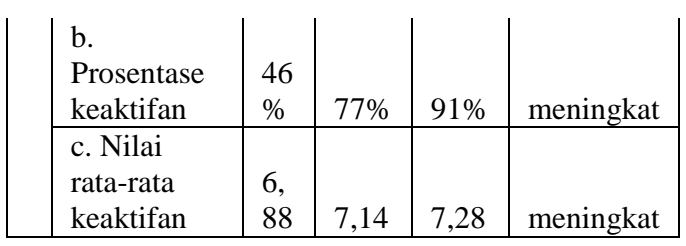

\section{Refleksi Terhadap Hasil Penelitian}

1. Refleksi Penelitian pada Siklus I

Pelaksanaan observasi awal yang merupakan hasil proses pembelajaran guru bidang studi standar kompetensi "Instalasi Video Game" menunjukkan hasil yang kurang optimal. Hal ini dapat di evaluasi dan di refleksikan dengan penjelasan berikut ini:

a. Tingkat emosional siswa terhadap materi pembelajaran sangatlah minim sekali, hal ini dapat di amati dari hasil penilaian sikap yang telah di berikan guru bidang studi, terbukti dari keaktifan yang rendah sekali dari siswa kelas XII AV.B. Sikap ini sangatlah berpengaruh pada tingkat penguasaan materi, apabila tingkat keaktifan rendah maka di pastikan hasil ulangan harian maupun penugasan juga rendah.

b. Perlu penggunaan media pembelajaran yang efektif pada standar kompetensi "Instalasi Video Game" supaya penyerapan materi menjadi lebih baik.

2. Refleksi Siklus II

Penggunaan macromedia di dalam penyampaian pembelajaran standar kompetensi "Instalasi Video Game" merupakan upaya terobosan di dalam penggunaan media pembelajaran. Media pembelajaran ini terbukti efektif sebagai media penyampaian materi pelajaran tersebut. Hasil yang tampak pada siklus II (kedua) menunjukkan adanya peningkatan prestasi belajar siswa kelas XII AV.B SMK Gamaliel 1 Madiun. 
Hasil yang menggembirakan ini, dapat di bahas dalam beberapa catatan berikut ini:

a. Macromedia merupakan media pembelajaran efektif di dalam pemberian materi standar kompetensi "Instalasi Video Game" pada kelas XII AV.B SMK Gamaliel 1 Madiun.

b. Peningkatan rata-rata prestasi kelas merupakan bukti bahwa macromedia lebih bisa di terima oleh sebagian besar siswa kelas XII AV.B SMK Gamaliel 1 Madiun.

\section{Refleksi Siklus III}

Siklus III (ketiga) merupakan pengembangan dari siklus II, dimana dalam hal ini peneliti menerapkan pola diskusi kelompok pada siswa kelas XII AV.B.

Pada kenyataannya bahwa dengan penerapan pola diskusi kelompok ini perkembangan prestasi belajar siswa kelas XII AV.B semakin meningkat di bandingkan dengan hasil sebelumnya.

$$
\text { Kemajuan ini sangat }
$$
menggembirakan sekali, sehingga perlu untuk di ungkapkan dalam pembahasan berikut ini:

a. Kombinasi antara penggunaan macromedia dengan penerapan pola diskusi kelompok siswa kelas XII AV.B terbukti mampu meningkatkan prestasi belajar siswa pada taraf yang memuaskan khususnya pada indikator nilai penugasan dan ulangan harian.

b. Pola kerjasama antar siswa dalam situasi berdiskusi mampu menciptakan suasana pembelajaran yang kondusif baik antara peneliti dengan siswa maupun antara sesama siswa di kelas.

\section{Kesimpulan}

Dari pelaksanaan penelitian pada kelas XII AV.B SMK Gamaliel 1 Madiun, maka dapat di tarik beberapa kesimpulan antara lain:

a. Media pembelajaran visual sederhana yang hanya berupa gambar-gambar sederhana, bukubuku, dan lain-lain terbukti belum mampu menunjukkan hasil prestasi belajar yang memuaskan pada siswa kelas XII AV.B SMK Gamaliel 1 Madiun.

b. Macromedia merupakan media pembelajaran visual modern, yakni di dukung dengan perangkat komputerisasi terbukti mampu meningkatkan prestasi belajar siswa kelas XII AV.B terutama pada standar kompetensi "Instalasi Video Game".

Proses pembelajaran pada standar kompetensi "Instalasi Video Game" yang di dukung dengan penggunaan macromedia dapat diterapkan sebagai media pembelajaran efektif di sekolah, macromedia dapat di pergunakan sebagai media Bantu utama di dalam penyampaian materi di depan kelas.

c. Macromedia mampu mewakili secara keseluruhan materi pembelajaran yang ada sehingga mampu meningkatkan prestasi belajar siswa kelas XII AV.B SMK Gamaliel 1 Madiun.

\section{Saran}

Sebagai akhir dari penyusunan penelitian ini, maka peneliti ingin memberikan saran kepada :

a. Siswa, untuk lebih giat lagi di dalam mempelajari dan memahami tentang macromedia, karena dengan macromedia ini siswa akan lebih mudah lagi di dalam menguasai meteri pelajaran di sekolah. 
b. Guru, semoga penelitian ini menjadikan sumber inspirasi di dalam pelaksanaan pembelajaran di sekolah terutama dalam hal pemakaian media pembelajaran.

c. Sekolah, semoga dengan penelitian ini sekolah lebih terpacu untuk menyediakan sarana dan prasarana berupa macromedia untuk penunjang kegiatan pembelajaran di sekolah.

\section{DAFTAR PUSTAKA}

Anita Lie. (2002). Cooperative Learning (Mempraktekkan Cooperative Learning di Ruang Kelas). Jakarta: Grasindo

Dwi Harsini. (harsini31@yahoo.com). 14 April 2011, Artikel Macromedia. Email kepada Nunus Wijoseno (w_nunus@yahoo.co.id).

Guntur Wibawa .2008 artikel internetPengertian Kreatifitas Siswa (http://gunturkomjar.blogspot.com/2 008/12/, artikel di upload senin 29 Desember 2008, di akses 10 April 2011).

Lugiyono. 2009. Penggunaan Media Visual LCD Proyektor Untuk Meningkatkan Hasil Belajar Pelajaran Produktif Pada Siswa Kelas III Audio Video SMK Negeri 1 Jiwan. PTK. Madiun:Dinas Pendidikan Kabupaten Madiun, hal:14-15).

Moh. Amin. (1981). Hakekat Science. Yogyakarta: FPMIPA IKIP Yogyakarta.

SMKN 1 Jiwan.2009. artikel pembelajaran Media Pembelajaran Berbasis TIK. (http://smkn1jiwan.blogspot.com/200 9/02/blog-post_11.html, artikel di upload bulan februari 2009, diakses 10 April 2011).

Sutrisno. (2001). Kurikulum Berbasis Kompetensi (Mata Pelajaran Fisika
SLTP). Jakarta: Puskur Balitbang Depdiknas.

Utami Munandar, 1987. Mengembangkan Bakat dan Kreatifitas Anak Sekolah. Jakarta: Gramedia 